\title{
Plan UK and Development Education - the contribution of an international development organisation to learning and understanding about global and development issues
}

Douglas Bourn Institute of Education, University of London, (UK) Miriam Kybird

\begin{abstract}
Plan International is a leading international development organisation that applies a rights based approach to achieving its mission of achieving lasting improvements in the quality of life of children in developing countries. In the summer of 2011, Plan in the UK made a decision to close down its development education programme, as part of a process of re-strategising to focus its organisational resources. Plan UK's development education programme illustrates many of the challenges that International Development Organisations (IDOs) face. Development education practice led by many IDOs tends to emphasise the relationship of education to social change and development goals. But if development education is perceived in terms of questioning and challenging dominant ideologies, and promoting differing voices and perspectives, then it can only be assessed in terms of its educational impact.
\end{abstract}

Keywords: International development, development education, global citizenship, children's rights, non-governmental organisations.

\section{Introduction}

In 2011, Plan UK, a leading international development organisation, closed down its development education department. Whilst it continues to engage in development education, it is now doing so at a much lower level of activity. Within the history of development education practice in many industrialised countries, a constant theme has been the changing nature of engagement and support from development organisations. A number of reasons were given by Plan UK for its decision to close down its development education department including reductions in funding, changes in UK government policies and an internal review resulting in changes in priorities.

This article identifies, primarily through an analysis and review of the policies and practices of Plan UK, the main themes and issues that emerge regarding the contribution, challenges and possible contradictions in International Development 
Organisations' (IDOs) engagement in development education. The article includes data gathered from research by Kybird (2011) based on interviews with and observations on the practices of key Plan UK staff. It does not aim to pass judgement on the quality of the work. Its aim is rather to identify themes that have emerged, contextualise them within broader debates and give some reflections on where Plan's activities were located within the broader IDO practices in the UK. A central theme is the relationship between how development education is perceived as an agent for social change, and wider development goals and objectives.

\section{Growth in support of development education since 2000}

Development education has been in existence in the UK since the 1970s through the leadership and practices of a small number of IDOs, notably Oxfam, Christian Aid, CAFOD and VSO, and a network of local Development Education Centres (Bourn, 2008; Harrison 2009; Osler, 1993). The election of a Labour government in 1997 and their Building Support for Development strategy (DFID, 1998) transformed the landscape and support for this area of educational practice. From being on the margins of education and also of the practices of many IDOs, development education was politically encouraged through the introduction of terms such as global citizenship, sustainable development and learning in a global society.

For development-focused organisations, the success of the Make Poverty History campaign and the challenges to achieve the Millennium Development Goals added an impetus to IDOs to consider how best they could engage and sustain public support for their activities. These initiatives also demonstrated the dangers of superficial support that could easily disappear. Where investment was put into indepth learning combined with personal engagement and experience, then support for development had potential for long-term support (see Darnton and Kirk, 2011).

This growth in support for development education was mirrored elsewhere in Europe, culminating in the 2005 European Consensus Document on Development Education supported by the European Commission, a range of national foreign affairs ministries and networks of International non-governmental organisations. This document stated:

The aim of development education and awareness raising is to enable every person in Europe to have life-long access to opportunities to be aware of and understand global development concerns and the local and personal relevance of those concerns, and to enact their rights and responsibilities as inhabitants of an interdependent and changing world by affecting change for a just and sustainable world' (EU Multi-stakeholder Forum 2005:5).

This document is significant because it recognises the contribution and approach many IDOs had undertaken for many years. These included the value of partnership working between funder and recipient, educator and learner and actors in the Global North and Global South. It also stated that a key theme of practice should be the recognition of the value of a 'rich variety of voices and perspectives', and parti- 
cularly giving voice to those who 'are marginalised from or adversely affected by global development' (Ibid:6).

Implicit in the Consensus document, but mentioned in other European focused material (Rajacic et al, 2010a,b; Krause, 2010), is the importance of a multi-stakeholder approach. This means securing the ownership and engagement in strategies and delivery of programmes of a range of bodies, including government at local, regional and national level, non-governmental organisations, educational bodies, universities, media, business, trade unions and Southern partners.

Another strand in the same European material is the emphasis on participatory learning methodologies and the promotion of critical thinking. Rajacic et al (2010a) make reference to good practice in development education including encouraging the learner to take on responsibilities, enabling autonomous choices and supporting confidence building.

The Consensus document also emphasised the importance of working with, and through existing systems and processes, particularly mainstream education such as the school curriculum. It suggests the need to develop common agendas with the other adjectival educations, ie. human rights, peace, environment and interculturalism. This again built on well-established practices by both NGOs and policymakers, seeing the value of working through established practices and bodies rather than establishing separate and distinct programmes.

\section{Themes and conceptualisations of development education}

Development education could be seen as one of the adjectival educations, if you see it as an area of educational practice located within and around discourses of development. It could also be seen as an approach that is about promoting knowledge about global issues within education. It could also be seen as a way of promoting some form of universal global viewpoint on global citizenship (Bourn, 2008).

There is however another way in which development education could be seen and that it is as a methodology and approach that has relevance to broader theories of learning, particularly critical pedagogy.

The rationale for this interpretation is that if one looks at the practices of organisations in many countries in the Global North, there are some common factors that suggest that development education has connections to the ideas of Paulo Freire and his emphasis on continuing reflection, questioning of knowledge and dominant orthodoxies, of empowerment and social change (Freire, 1972; Darder, Baltodano and Torres, 2009).

Giroux suggests that critical pedagogy needs to create new forms of knowledge and break down disciplinary boundaries (Giroux, 2005). McLaren (2009) in defining critical pedagogy emphasises not only the importance of forms of knowledge but also dominant and subordinate cultures and consequent influences of power and 
ideology. This questioning of dominant myths and ideas, to go beneath the surface and look at root causes and social context, lies at the heart of critical pedagogy (Shor, 1992).

These theoretical viewpoints relate closely to the practical manifestations of a 'critical development education' that can be summarised under the following themes.

Firstly, a key theme of development education practice is the promotion of the interdependent and interconnected nature of our lives, the similarities as well as the differences between communities and peoples around the world (Regan and Sinclair, 2000; DEA, 2002)

A second theme is about ensuring the voices and perspectives of the peoples of the Global South are promoted, understood and reflected upon along with perspectives from the Global North (Ohri, 1997; Patel, 2010). This means going beyond a relativist notion of differing voices to one that recognises the importance of spaces for the voices of the oppressed and dispossessed (Andreotti, 2008).

Thirdly development education can seek to encourage a more values-based approach to learning with an emphasis on social justice, fairness and the desire for a more equal world (Abdi and Shultz, 2008).

Fourthly an important element, implicit in Freirean approaches, is the incorporation of styles of learning that encourage empowerment, participation and personal reflection within the context of human rights education (Regan and Sinclair, 2000).

Finally, development education can promote the linkage between learning, moral outrage and concern about global poverty, and wanting to take action to secure change (Oxfam, 2006).

\section{International development organisations and development education}

The engagement of IDOs in development education poses major questions regarding the relationship between development and development education, the purpose of development education and the relationship between education and personal and social change.

IDOs have been central to securing public support for aid in the UK and other industrialised countries since the 1970s but because of their need for public support and governmental funding, their role has tended towards an acceptance rather than a questioning of the purposes of development. Hudson and van Heerde-Hudson (2012) have asked what is the purpose of building support for development - to be accommodating to existing policies, to share them or even to criticise them?

Whilst Bebington et al have called for NGOs to offer 'alternatives to dominant models, practices and ideas about development' (2008:3), the realities of fundraising and support for programmes in the Global South have increasingly led them to play an uncritical role.

48 International Journal of Development Education and Global Learning 4(2) 2012 
Yet IDOs have seen their relationship to development education as being based on the assumption that resourcing and promoting learning about global and development issues in the Global North will result in a call for action for global social change. This approach is based on a causal linkage between learning, empowerment and social action. But learning is a complex, self-led and self-constructed process. The factors that influence learning may come from a number of informal situations that could outweigh more formal learning influences. This means that when we look at learning about development issues, the ways in which the learner may respond to or interpret the knowledge outlined could be influenced by a range of other external factors. This is particularly important in the context of development issues because, as Andreotti (2007) has stated, there is a need to understand the complex ideological and social influences that have impacted upon the learner, including influences of colonialism and attitudes towards charity, not respecting or valuing the views of others.

Scheunpflug and Asbrand (2006) have criticised IDOs for their lack of attention to the importance of competencies and the linkages between knowledge and skills, and their overemphasis on individual action and change. Gearon (2006), suggests that NGOs in education 'derive their raison d'etre from an emancipatory role of education: they exist to campaign, as advocacy groups, as champions of social structural change, often presenting radical agendas which challenge democratically elected governments...' (ibid.12). Marshall (2007) has commented as follows:

Overall the curriculum strategy of global educators and NGOs appeared to be aligned with the broader call for 'active' global social justice. Indeed, global educators were sometimes more concerned with the 'how' of global education rather than the 'what', in other words there appeared to be more clarity about the affective and participatory domains of global education that the cognitive (Ibid:82).

This article, whilst noting these observations about IDO practices, aims to take the debate further, through the example of a specific organisation, Plan UK, in order to review how development education may have been seen in relation to broader organisational and development goals.

\section{Rationale for engagement in development education}

IDOs' rationale for engagement in development education is very varied. Whilst some might subscribe to and support approaches outlined in the Consensus document, for others the pressure is to see education as a mechanism for securing additional income, for communicating information and key messages about their activities or securing potential 'global activists' and supporters for the future.

An example given by the Irish Catholic-based development NGO, Trocaire, in 2011 provides a good summary of the rationale of a number of organisations:

Education is key to raising pubic awareness of development so that the public understand the impact of their own actions. INGOs must understand and respond to public demand for more 
ownership and engagement. (and) ... build a global culture of solidarity with closer links to social movements. INGOs have a unique ability to link different groups and communities and offer a vehicle for citizens in wealthy countries to express their concern and solidarity (Trocaire, 2011:15)

This connection between awareness raising, learning and action for change has been a theme of both the aims and the practices of many IDOs across Europe. Krause (2010) summarises these elements as follows:

- inform and raise awareness of development issues

- change attitudes and behaviours

- enable understanding of causes and effects of global issues

- mobilise citizens through informed action (Krause, 2010).

What is distinctive about the approach of IDOs from say the European Consensus document is the linkage between awareness raising, learning and informed action, with an emphasis on empowerment and democratic engagement to secure global social change.

For example, staff in Plan UK felt that development education had various purposes within the organisation, of which action (particularly in terms of active audience development and youth engagement) was seen as pivotal (Kybird, 2011:39):

Development Education:

- Teaching young people about specific development concerns

- Involving young people from the Global South in programming

- Providing teaching and learning resources to the UK educational sector

Creating an audience for:

- Showcasing organisational work

- Fundraising initiatives

- Campaign activities

Youth engagement:

- Showcasing young people's voice and work

- Having young people represented in organisational programmes

Providing 'substance' for other departments' activities

- Providing school venues for MP visits

- Providing overseas placement opportunities for corporate volunteers

For most IDOs there would also be an underlying values base to their practice, whether or not Christian, as in the case of Catholic-based organisations around Europe such as CAFOD in the UK, which refers to the values of compassion, solidarity, stewardship and hope as central to its ethos and identity ${ }^{1}$. Another 
example is HIVOS from the Netherlands which is a humanist-based organisation which emphasises global social justice ${ }^{2}$. UNICEF on the other hand focuses its educational work around the UN Convention on the Rights of the Child. The organisation 'strives to establish children's rights and enduring ethical principles and international standards of behavior towards children'.

In their review of funding for development education for the European Commission, Rajacic et al (2010a) noted that the emphasis on 'challenging global injustice and poverty' was identified as the ultimate goal along with challenging misinformation and stereotypes, encouragement of active participation and understanding globalisation, and engagement of civil society as the means to achieve this (Ibid: 118).

Another theme that could be identified is the need for differing viewpoints and perspectives, as governments and curriculum bodies often only provide one approach. For a healthy democracy and to ensure representation of a range of perspectives, IDOs can provide alternative viewpoints. IDOs have Southern partners and if development education is to ensure that the voices of the dispossessed are included in any learning process, then they can play an important role in providing the spaces for dialogue .

\section{IDO practices in development education}

A tension in the practices of many IDOs in relation to development education because of the perception of the causal linkage between awareness raising, learning and action is that learning activities will be seen as being measured by their influence on campaigns, advocacy or fundraising. A recent UK study on the practices of IDOs suggests that campaigning, advocacy and fundraising can be more effective if they are built upon an informed and engaged supporter base (Darnton and Kirk, 2011).

There is an argument that an IDO's role could be simply to provide information about development issues, projects and campaigns, perhaps in a form that is userfriendly for young people. Providing information, or even opinions on issues, campaigns and policies, offers an important resource for people working in education. ActionAid has a global links website that can be used by both young people and teachers ${ }^{4}$. Others such as Oxfam ${ }^{5}$, Christian Aid $^{6}$ and $\mathrm{CAFOD}^{7}$ also have information and materials directly aimed at teachers and young people. Some organisations look at specific areas, such as British Red Cross at humanitarian law and disasters ${ }^{8}$, Practical Action at sustainable technology and climate change ${ }^{9}$, and UNICEF at children's rights ${ }^{10}$.

Secondly, and at the other end of the spectrum, many IDOs are concerned with securing global social change, to eliminate global poverty and secure a more just world. Key to securing this change is the engagement and support of the public in 
campaigning on specific issues, whether on debt, climate change, trade or more broadly to 'making poverty history'. Many young people are concerned about global issues and wish to take action to secure change. Therefore it could be argued that a legitimate activity for IDOs is to campaign and involve people, young and old, in activities that can secure change. This approach can be seen in some of the work of Oxfam, ActionAid, Christian Aid and CAFOD for example.

Thirdly, and linked to these two areas, is the role of an IDO in promoting and securing support for its particular perspective or value base, the ethical dimension to its engagement in education. Within a healthy democracy, it can be argued that the views, perspectives and approaches of an IDO need to be drawn to the attention of society more widely, whether young people or adults. But even if the organisation sees its role as merely providing information, this in itself brings with it particular perspectives and values. Therefore a clear pronouncement of the value base and perspective of an IDO is important. Examples of this can be seen in, say, CAFOD and its promotion of a social justice perspective and compassion, 'We act based on principles of compassion, solidarity, stewardship and hope. ${ }^{11}$

But all of these approaches still pose the question of how the IDO sees its role in relationship to processes of learning; and how it might therefore see development education - as an end in itself, rather than as a means to an end. A key indicator of the seriousness and depth of an IDO's engagement in learning could be argued to be the extent to which it has identified its contribution to broader learning goals of both the educator and the young person. This could be seen in terms of the connections being made between the learners' own perceptions and understandings about the world, their identities, social and cultural influences and how they can be most effective. Key to this is what Think Global (formerly the Development Education Association) calls 'global learning', promoting 'critical and creative thinking', open-mindedness to difference but within a framework of an understanding of global issues and power relationships (Brown and Shah, 2009).

This therefore suggests that an IDO would need to consider its contribution to a broader learning process. This does not mean that organisations should not produce resources or put forward a particular interpretation. Rather, it suggests they should be explicit about the values and perspectives they are adopting, and recognise that their engagement can and should only be partial, alongside other interpretations and other approaches.

It is within these debates and reflections on the contribution of IDOs that this paper now addresses the specific contribution that Plan UK has made.

\section{Plan International}

Plan International was formed in 1937 as the Foster Parents Plan for Children in Spain. From initially supporting children during the Spanish Civil War, then those in 
war-torn Europe and then beyond Europe, the organisation has today grown to become a global children's charity, placing the right of every child to fulfill their potential at the heart of its mission.

Plan's work is informed by the UN Convention of the Rights of the Child, based on the recognition of children and young people as citizens with their own rights and responsibilities; children are at the centre of all of Plan's work.

Plan is an international organisation with 20 national offices in both the Global North and the Global South, focusing on a mix of fundraising, programme support, advocacy, campaigns and development education. A considerable number of Plan's national offices have had development education programmes, determined by national priorities in terms of education, capacity of the organisation and policy priorities.

In 2002, Plan in the UK began to move from a more service-delivery oriented programming approach to a rights-based approach called 'child-centred community development' (CCCD). CCCD places children at the centre of all of Plan's work, and is grounded in human rights instruments and principles, particularly (but not exclusively) those set out in the Convention on the Rights of the Child. An independent review of the CCCD approach conducted in 2007 stated that Plan has made a significant contribution to realisation of the Convention on the Rights of the Child, and to fulfilling the Millennium Development Goals (Plan, 2007:2).

CCCD has meant Plan gradually shifting away from traditional needs-based service delivery to a rights-based model in which participatory, child-centred community development is complemented with initiatives aimed at duty-bearers at district and national levels. (Ibid:12)

Plan sees its approach as facilitating children, families and communities to be active and leading participants in their own development. For Plan, there is a causal link between the denial of rights and poverty and, as a consequence, power. Empowerment of children, families and communities is therefore seen as key to the work of this IDO. Plan also recognises the need to work at different levels, with differing timeframes depending on the aims, urgency of need and likelihood for change (Plan, 2010:38).

This approach of Plan's, based around CCCD, is distinctive within the international NGO community through its emphasis on change at different levels to improve children's lives, and empowering young people to create change in their own communities. This has implications for Plan's Development Education programme because of the emphasis upon social change, as distinct from simply building understanding and structural questions around aid and development. 


\section{Evolution of Plan UK's development education programme}

During the first decade of the twenty-first century, Plan UK invested significantly in Development Education, developing a large staff team and programme of activities. Underpinning many of its strategies and programmes since 2001 were the promotion of participatory learning processes in which, through mutual learning, children and young people in the UK and the Global South gained knowledge and understanding of global issues that affected them and of how their lives were interconnected.

Behind the evolution of the strategy was the emphasis on the value of direct humanto-human contact. The strategy suggested this would 'reduce feelings of alienation and powerlessness, and foster an experience of shared goals and aspirations'. Plan's role was seen to be 'linking people together whose common goal is to enable children to reach their potential'. 'Linking people', it was suggested, 'helps build an understanding and respect for different communities and cultures'.

This approach has been supported by a number of studies that show the transformative impact of direct experience and personal contact (Davies and Lam, 2010), but as others have shown, there are also limitations because of the nature of the power and cultural relations that might underpin these relationships (Jorgenson, 2010).

What is significant about the evolution of Plan's development education strategy is a recognition that it was potentially operating within a crowded market place; it needed to make sure it was not duplicating the work of others and that its materials were directly related to curriculum and learner needs. The strategy noted the potential added-value role of the organisation's UK development education programme as follows:

- use of the internet and direct contacts in the South to enable learning to take place;

- ensuring Plan's 'culture of learning' from the South and building relationships are embedded in its practices;

- child-focused development and work on child participation as a distinctive contribution to UK schools (Plan, 2001:10).

From the development of a strategy and some initial pilot work with schools between 2001 and 2003, the following development education activities evolved within Plan UK that reflected aspects of these themes but also responded to a rapidly changing external climate in schools, with opportunities such as Commission for Africa in 2005 and projects around anti-slavery and climate change.

By 2010, the development education programme could be seen as covering the following:

three Development Education project activities; 
a specialist support function to other programme areas as and when needed;

- production of a digital learning resource library for UK educationalists.

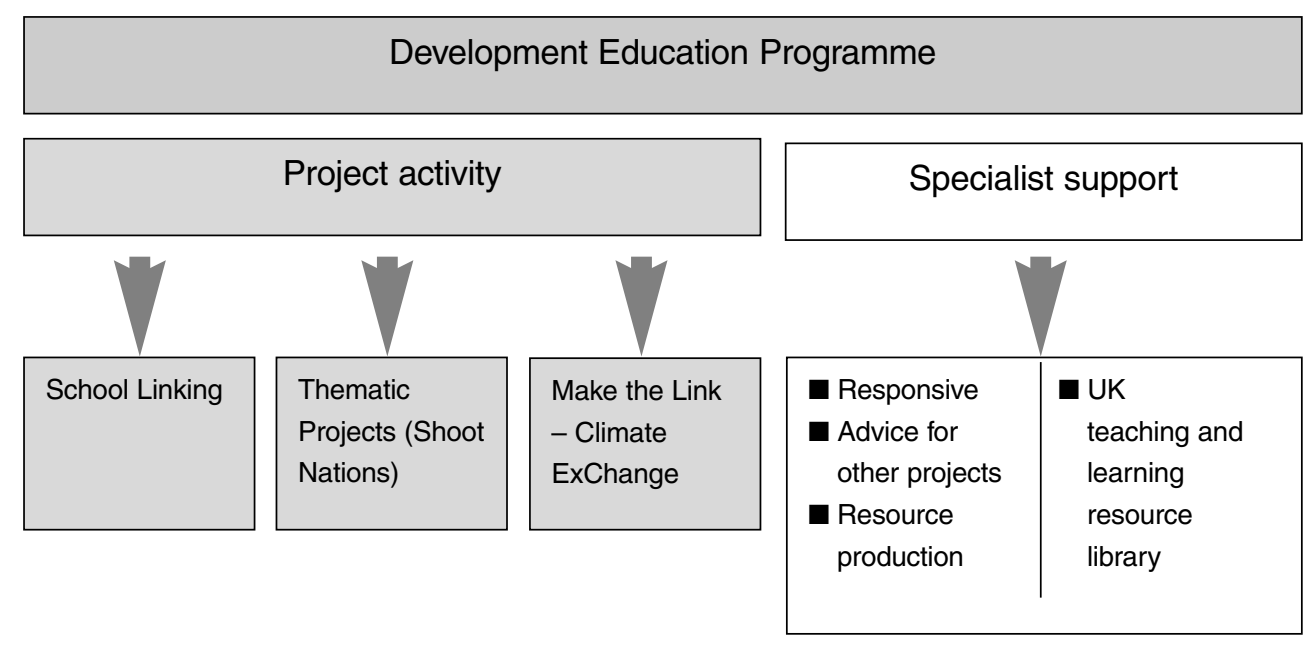

Table 1: Structure of Plan Development Education

These activities, whilst reflecting Plan's core mission around CCCD, also demonstrated a feature of many development education projects, being time bound with specific objectives often related to external funding influences. The thematic work had sat in communications and been seen as a way of raising awareness about specific issues. In recognition of this increasingly diverse range of activities, a more focused strategy was developed in 2010 that was not fully implemented.

This learning-focused approach was however clearly affected by how the development education programme was perceived within the organisation. For example, where the development team is located, in relation to areas such as campaigning, advocacy, communication and programmes, can tell us a great deal about the organisational view of development education. For example if a development education team is located in a Communications department then the focus is naturally towards raising awareness and communicating messages. If the team is located in an Advocacy or Campaigns department the pressure is to demonstrate connections between learning and action. What is noticeable is that between 2001 and 2010 the team's location in relation to these areas moved around, or individual activities were located in different places. Only between 2010 and 2011 was the team brought together, and then it was located within the Programme department. This resulted in pressure on the development education team to demonstrate connections to programmes within the Global South, and therefore to broader development objectives. 
An example of the consequences of this location of development education can be seen through its Climate ExChange - Make the Link project. This project was one of the main projects delivered by the development education team. It aimed to link young people in three African Countries with young people in three European countries, to learn about and debate issues around Climate Change and how it affects their lives.

In discussions, the development education team stated that the key outcome for them was to help young people learn about, discuss, debate and question issues around Climate Change with their peers around the world, to learn about other perspectives and gain more understanding of the bigger picture of causes and effects. For the team, the outcome of learning was to create more informed and independent thinkers who could then potentially go on to make wider choices (eg. lifestyle changes) themselves. However, discussions with other Programme team members showed that from their point of view the learning process was only valuable if it led to a direct action or change; learning for learning's sake was not enough (Kybird, 2011).

This is a key question for Development Education in IDOs; where does the Development Education programme stop and other programmes or activities start; and therefore how do you define and identify success for the Development Education programme?

\section{Relationship between learning - action - change}

The issues to emerge in the Climate Exchange project are a reflection of the wider tensions and debates within the organisation, and in many other IDOs, about the purpose of development education. At the time Plan UK decided to close down its development education department, the following was the perceived vision:

Development education is learning about the world around us; the issues and opportunities that affect people, the systems and structures that affect people's lives and the influence and impact we all have on the world. Development education is also an active learning experience; using that learning to make positive and informed change happen for ourselves and others (Plan UK, 2011a:2).

This definition of development education went on to suggest that the role of Plan was more than giving young people information about global issues, but also to give them:

The skills and opportunities they need to make positive changes in the world around them, now and in the future. We want to help young people look more closely at diverse global situations, to understand, question and have ideas about how to get involved' (Ibid).

This approach to development education by Plan in 2011 is significantly more learner-focused than earlier manifestations where there was a greater emphasis on the relationship between learning and action (Plan, 2003). In addition this 2011 approach provides an opportunity to demonstrate the role of development educa-

56 International Journal of Development Education and Global Learning 4(2) 2012 
tion in both the Global South and North. For example, the definition of development education in 2011 goes on to suggest the value of mutual learning and interconnectedness between young people around the world:

Our experience is that young people learn best when connected to each other and communicate directly (Plan, 2011a:2).

However whilst an evolving definition of development education may have emerged within the organisation, evidence from Kybird's (2011) research suggests that differing perceptions still existed and this remained an ongoing source of tension. Differing perceptions were usually related to its value to a particular area of work. For example:

'Representatives from the Communications Department saw Development Education as a mechanism by which to reach particular audiences and raise the INGO's profile within certain sectors or fora, whereas representatives from the Supporter Relations team talked about the purpose of Development Education being to educate supporters in the aims and ethos of the INGO' (Kybird, 2011:38).

\section{Plan UK and empowering young people to engage in international development}

As already identified, a distinctive feature of Plan's programmes globally was to empower young people, to enable them to have the skills to engage effectively on their own terms. The aim was that all aspects of Plan UK's development education activities were to include young people's participation, empowerment and action as a key theme.

This case study (Kybird, 2011) showed that Plan considered action and change in:

designing educational programmes to allow young people and learners to do something real with their learning through having the option of interacting with wider organisational areas. Action needs to be seen in two ways when looking at a learning experience; as a potential outcome of learning and as a way of learning (Ibid:42).

However there were ongoing tensions between how the development education team and the wider organisation viewed the place, purpose and rationale for action within the learning process:

For the team the outcome of learning was to create more informed and independent thinkers who could then potentially go on to making wider choices (eg. lifestyle changes etc) themselves. However, discussions with other Programme team members showed that from their point of view the learning process was only valuable if it led to a direct action or change; learning for learning's sake was not enough (Ibid:48).

An example of this approach can be seen through the promotion of the Student Steering Committees within the school linking programme. To ensure that the linking programme was child-led, participating schools in Senegal, Sierra Leone, Malawi, Kenya, China and UK formed Student Steering Committees (SSCs), tasked with developing plans for linking programme activities and action plans, including 
informing about and engaging other pupils and the wider school community with the activities of the programme (Plan UK, 2011b).

The student steering committees initiative was seen to a certain extent as the first step towards young people's governance, because they gave young people the experience of decision making, and enabled the wider community to gain experience and understanding of young people's governance in a defined way.

Their remit was to act as a consultative group for the school linking programme, and to lead on decisions around programme development. However, in some schools they became the mouthpiece of the student body. As a group, the body of students often had the opportunity to speak to teachers and Head teachers about issues wider than the school linking programme, bringing their views to the power holders in their community (Ibid).

In terms of increasing their educational skills, a study by Woods (2011) for Plan UK found that at one UK school, young people interviewed emphasised the skills they had gained through their Steering Committee, through taking responsibility and looking after the budget, for example. The Deputy Head suggested that taking such initiative was not common to the ethnic majority of pupils in the school, but the School Linking Programme had encouraged pupil enterprise and initiative. In Malawi, pupils in all five Steering Committees confirmed that they, rather than teachers, took the lead in steering the school linking activities. The Malawi report highlighted co-operation and the development of pupil leadership, communication, governance and peer counselling skills among the benefits of the Steering Committees (Ibid:25). In Senegal, the evaluation recorded that skills in decision making, managing budgets and conducting meetings developed as a result of the training offered to members of Steering Committees. In China the researcher felt that 'The students have more willingness and intention to participate, and they have more confidence and courage to actively involve [themselves] in making decisions and taking actions about student affairs'(Ibid:15).

A more challenging theme to emerge from evaluations undertaken is the extent to which there is evidence of changes in the values base towards children and peoples' elsewhere in the world. Wood's study (2011) suggests from interviews with young people that there was a noticeable development of empathy and concern for social justice, which was evidenced when 27 of the 37 pupils interviewed claimed that various aspects of disadvantage constituted the biggest problem facing young people around the world today.

Finally in terms of pupils, there was evidence that Student Steering Committees had enabled pupils to develop not only their communication skills, but also their abilities to organise themselves and events, and show that from their actions, changes could be seen. 
At a broader school level there is evidence to suggest that a link has resulted in increased interdisciplinary activities, including special days with a suspended timetable, using noticeboards, and visual displays that portray information about the partner school.

Edge et al (2010) stated that 'Teachers and students involved in SSC's [Student Steering Committees] gain genuine leadership experience which has a large potential influence on their futures. SSCs involve students in making decisions, taking responsibility, organising, presenting, arguing, encouraging and stimulating other students or adults to help in a common cause. They are accountable for their actions and must plan ahead to foresee consequences. Students interviewed tended to confirm these skills as arising from their work on the SSCs.'

SSCs were provided with on-going support and resources, and were trained in roles and responsibilities, how to hold a meeting, leadership, decision-making practices, governance skills, managing an event in their school, and campaigning. Coordinators met with students during school visits to give on-going advice and support.

These evaluations suggest there is a potential relationship within a piece of development education between learning and action, if the focus is on the empowerment of young people themselves, rather than learning towards pre-determined goals. It is in this context that Plan UK's work was potentially distinctive, because the whole focus of its broader programme work has been on child-centred development that builds on the needs of individual children and young people.

\section{Lessons from Plan's contribution: the role of IDOs in development education}

This review of Plan UK's engagement in development education reflects many of the tensions and contradictions outlined earlier. For example there is evidence of pressure for development education to be located in relation to development and activist notions of change. There are also assumptions that mere dialogue and engagement with partners in the Global South will encourage mutual learning, thus ignoring the influence of power and dependency relationships.

But despite these comments, Plan UK's engagement does pose some wider issues that have perhaps not been addressed by other commentators who have reviewed IDO practice in development education.

Firstly an IDO, if it recognises the central role of learning for its own sake within its development education practice, can make an important contribution to education, by presenting different perspectives and voices than, say, the state or the media.

Secondly an IDO can, if it sees its role as a global organisation and works in partnership with voices from the Global South, promote values and approaches towards learning that challenge dominant orthodoxies about aid and development. 
This is an opportunity, particularly for an organisation like Plan that has an approach based on human rights, child-centred development and empowerment.

Thirdly, and following on from the above, if a critical pedagogical approach is taken that facilitates the encouragement of social and political engagement, then development education does have a potentially transformative role in society.

However as the examples from Plan UK have demonstrated, there are many obstacles and difficulties that bar moving towards this approach. Within an IDO there are always going to be pressures regarding fundraising, policy profile and the need for short-term change.

\section{Conclusion}

This article has aimed, by reviewing the practice and debates within one particular IDO, Plan UK, to demonstrate the tensions, opportunities and challenges that exist for a development education programme within such an organisation.

International Development Organisations can make a valuable contribution to the practices of development education. They can provide an voice and a perspective independent from government, and can promote a particular focus that, if seen as one amongst many perspectives, enrich learning about global and development themes. However, as suggested from the example of Plan UK, there are tensions between the educational aims of development education and institutional goals of profile raising, advocacy and fundraising.

As mentioned earlier in this report, IDOs have tended to measure development education in relation to development goals. It is suggested here that if an approach is taken that looks at the relationship between development education and educational development goals, where there are areas of overlap, mutuality and promotion, and also space for voices from the Global South, then Plan UK had a potentially unique contribution to make. The focus on child-centred development could have provided the opportunity to make these connections.

IDO programmes including those of organisations like Plan want to encourage learners to value and support their work. This directly relates to agendas around fundraising, but also it makes an assumption that development is a good thing. An IDO's engagement in education is inevitably going to be related to endorsement of this assumption.

This suggests that, rather than as Gearon (2006) implies, IDOs being seen as radical, and as change agents, they could equally be seen as conservative and protectors of the status quo, since it is in their interests to promote the impact of aid and development in an uncritical manner.

There is considerable evidence from both the UK and elsewhere in Europe that IDOs have played an important role in raising the profile of development education, producing some valuable resources, offering quality support to many teachers and

60 International Journal of Development Education and Global Learning 4(2) 2012 
educators and acting as providers of 'real time expertise' in development practice and issues. However this should not detract from the need to reflect, assess and research the impact of IDOs' practice, particularly in relationship to broader educational and development goals. What above all is needed is a recognition by both IDOs and other stakeholders involved in development education that a more open debate about the location of learning and education within their practice would help to resolve the question: does development education have a role in itself within an IDO; or is it merely a means towards achieving an IDO's pre-determined goals and objectives?

Plan UK closed its development education department because in the end it could not demonstrate the impact of this area of activity on its broader development goals. This is perhaps not surprising, given the lack of debate on the relationship between development education and development.

Douglas Bourn is Director of the Development Education Research Centre at the institute of Education, University of London, and author of numerous articles on development education, global citizenship and global perspectives in education

Miriam Kybird is a freelance development education consultant and was Head of Development Education within Plan UK from 2010 to 2011.

\section{Notes}

1 www.cafod.org.uk/vision

2 www.hivos.nl

3 www.unicef.org.uk/pages.asp?page $=62$

4 www.globallinks.org.uk/about/your_questions_1.html

5 www.oxfam.org.uk/education/

6 http://learn.christianaid.org.uk/TeachersResources/

7 www.cafod.org.uk/resources

8 www.redcross.org.uk/TLC. asp? $i d=86219$

9 www.practicalaction.org.uk/?id=education

10 www.unicef.org.uk/tz/index.asp

11 http://www.cafod.org.uk/about-us/vision

\section{References}

Abdi, A. and Shultz, L. (ed.) (2008) Educating for Human Rights and Global Citizenship, Albany, State University of New York Press.

Andreotti, V. (2006) Soft versus critical global citizenship education, Policy and Practice, 3, Belfast, Centre for Global Education, pp.40-51.

Andreotti, V. (2010) Global Education in the 21st Century: two different perspectives on the post of postmodernism', International Journal of Development Education and Global Learning, 2 (2) 5-22.

Asbrand, B and Scheunpflug, A (2006) Global Education and Education for Sustainability. Environmental Education Research, 12(1), p. 33-46.

Bebington, A. Hickey, S. and Mitlin, D. (2008) 'Introduction: Can NGOs Make a Difference? The Challenge of Development Alternatives' in Bebington, A. Hickey, S. and Mitlin, D (eds.) Can NGOs Make a Difference? The Challenge of Development Alternatives, London, Zed Books. 
Bourn, D. (2008) Development Education: Towards a re-conceptualisation, International Journal of Development Education and Global Learning, vol.1,5,.5-22.

Brown, K. and Shah, H. (2009) Critical Thinking in the Context of Global Learning, DEA Thinkpiece, available at www.think-global.org.uk/yhinkpieces.

Bryan, A. and Bracken, M. (2011) Learning to Read the World- Teaching and Learning about Global Citizenship and International Development in Post-Primary Schools, Dublin, Irish Aid.

Darnton, A. and Kirk, M. (2011) Finding Frames: New Ways to Engage the UK Public in Global Poverty, London, BOND.

Darder, A., Baltodano, M.P., Torres,R. D. (ed.) (2009) The Critical Pedagogy Reader, New York ,Routledge.

Development Awareness Raising and Education (DARE) Forum (2004) Definition of Development Education, available on http://www.deeep.org/dear-definitions (last accessed 29 May 2012).

Davies, D. and Lam, E. (2010) The Role of First-Hand Experience in the Development Education of University Students, International Journal of Development Education and Global Learning, 2.2.35-52.

Edge, K., Creese, B., Frew, E. and Descours, K. (2011) Plan School Linking-Research and development findings - third year, London, IOE/ Plan UK.

European Union Multi Stakeholder Forum (2005) European Consensus on Development Education, Brussels,CONCORD, available via www.deeep.org.

Freire, P (1972) Pedagogy of the Oppressed, London, Penguin.

Giroux,H. (2005) Border Crossings, New York, Routledge.

Harrison, D. (2009) Oxfam and the rise of development education in England from 1959 to 1979, Unpublished PhD, Institute of Education, University of London.

Hudson, D. and van Heerde, J. (20102) 'A mile wide and an inch deep-Surveys of Public Attitudes towards Development Aid', International Journal of Development Education and Global Learning, 4.1. 5-24.

Krause, J. (2010) European Development Education Monitoring Report - Development Education Watch, Brussels, European Multi-Stakeholder Forum.

Kybird, M. (2011) A Plan UK Case Study: What have been the key organisational challenges and opportunities encountered when designing and implementing a Development Education programme in an INGO? Dissertation submitted as course requirement for the MSc in Education for Sustainability, London South Bank University.

Marshall, H. (2007) Global Education in Perspective: fostering a global dimension in a secondary school, Cambridge Journal of Education, 37.3, 355-374.

Mclaren, P. (2009) Critical Pedagogy: A Look at the Major Concepts, in Darder, A., Baltodano, M.P.,Torres,R.d. (ed.) The Critical Pedagogy Reader, New York ,Routledge,61-83.

Ohri, A, (1997) The World in Our Neighbourhood, London, DEA.

Osler, A. (1994) Development Education, London, Cassell.

Oxfam (2006) Education for Global Citizenship. Oxford, Oxfam.

Patel, S. (ed.) (2010) Building Capacity, London, DEA.

Plan International (2003) Draft Education Strategy, Woking, Plan International.

Plan International (2007) The effectiveness of Plan's child-centred community development: Plan Programme Review 2003-2006. London, Plan UK.

Plan International (2010) Promoting Child Rights to end child poverty: Plan Programme Guide, London Plan UK. Plan UK (2001) Development Education Strategy 2001-2003 - internal discussion paper, London, Plan UK.

Plan UK (2006) The effectiveness of Plan's child-centred community development: Plan programme review 20032006, London, Plan UK.

Plan UK (2011a) Development Education Strategy 2011 Unpublished paper, Plan UK (2011b) Learning from innovative partnerships: exploring the Plan School Linking programme, Unpublished Report, London Plan UK.

Plan UK (2011b) Promoting Student Participation in School Linking Projects: A toolkit for teachers and students, London, Plan UK.

Rajacic, A., Surian, A., Fricke, H-J., Krause, J., Davis, P. (2010a) Study on the Experience and Actions of the Main European Actors Active in the Field of Development Education and Awareness Raising - Interim Report, Brussels, European Commission.

62 International Journal of Development Education and Global Learning 4(2) 2012 
Rajacic, A., Surian, A., Fricke, H-J., Krause, J., Davis, P. (2010b) DEAR in Europe - Recommendations for Future Interventions By the European Commission: Final Report of the Study on the Experience and Actions of the Main European Actors Active in the Field of Development Education and Awareness Raising, Brussels, European Commission.

Regan, C. (2006) 80:20 - Development in an Unequal World, Dublin, Ireland.

Regan, C. and Sinclair, S. (2000) Development Education and Human Rights Education in Britain and Ireland: Present and Future Challenges: The Development Education Commission: Final Report, Birmingham, 80:20 and TIDE.

Shor, I. (1992) Empowering Education: Critical Teaching for Social Change, Chicago, University of Chicago Press. Smith, M. (2004) Contradiction and change? NGOs, schools and the public faces of development. Journal of International Development, Vol. 16 , 5, 7-41.

Trocaire (2009) Trocaire and Development Education: Remembering the Past, Signposting the Future.

Trocaire (2011) Leading Edge 2020, Critical Thinking of the Future of International Development.

Wood, D. (2011) IPads and eye openers - The Plan School Linking Programme, London, Plan UK. 
The only journal of its kind anywhere, IJSD is an international, double blind peer-refereed journal which provides a forum for multidisciplinary dialogue about the issues and challenges associated with marginalised, and potentially disengaged, children and young people. It represents the perspectives, theories and insights of academics and scholar practitioners from a range of disciplines and backgrounds, and particularly those whose research interests fall within the intersections between education, youth studies, sociology, mental health and criminology. The journal publishes articles on issues and theories surrounding school disaffection and the wide range of strategies, both individualised and structural, that are being used to keep children and young people from becoming disengaged from learning. IJSD publishes a mix of academic and practical articles, and promotes the voices of young people from diverse cultural groups around the world who are or have disengaged from school.
Editors:

Ross Deuchar

University of the West of Scotland, United Kingdom

Linda J. Graham Macquarie University, Australia

Associate Editor Practitioner Research: Geoff Bright

Manchester Metropolitan University

First published 2003. ISSN: 1478-8497 (print), 1747-9207 (online). Two issues: Spring and Autumn

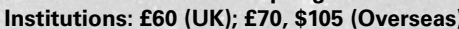
rivate addresses: $\mathbf{£ 4 2}$ (UK); $\mathbf{5 2}, \mathbf{\$ 7 8}$ (Overseas) Back Issues: $₫ 31, \$ 47$ each Print and online: $\mathbf{f 1 8 8 ,} \mathbf{\$ 2 8 2}$ Institutions only Trentham Books http://www.trentham-books.co.uk/acatalog/The_International_Journal_on_School_Disaffection.htmI 